\title{
EVALUATION OF QUALITY OF LIFE AND LIVING SPACE IN THE BALATON DESTINATION (HUNGARY) BASED ON THE PERCEPTIONS OF THE LOCAL RESIDENTS AND THE OWNERS OF SECOND HOMES
}

\author{
Katalin Lőrincz ${ }^{1}$, Annamária Sasné Grósz² ${ }^{2}$ János Csapó ${ }^{3}$
}

\footnotetext{
1 Department of Tourism, University of Pannonia, Veszprém, Hungary; ORCID: 0000-0001-6750-7146, e-mail: lorincz.katalin@gtk.uni-pannon.hu

${ }^{2}$ Department of Marketing, University of Pannonia, Veszprém, Hungary; ORCID: 0000-0002-6971-1121, e-mail: sasnegrosz.annamaria@gtk.uni-pannon.hu

${ }^{3}$ Institute of Marketing and Tourism, Faculty of Business and Economics, University of Pécs, Hungary; ORCiD: 00000001-6645-8629, e-mail: csapo.janos@ktk.pte.hu
} 
Abstract: The study aims to reveal the evaluation of quality of life (QOL) factors of the local residents and the owners of the second homes from a regional perspective. As a case study we analyse the second most important tourism destination of Hungary, Lake Balaton in terms of evaluation of quality of life and living space within the scope of three target groups, two groups of local residents (who live there and work there, and who live there but work elsewhere) and the owners of second homes. The authors believe that the understanding of the decisive factors of quality of life and living space is becoming increasingly important in the successful management of local governments and in the field of sustainable tourism development and tourism management as well. The authors also intend to detect and understand the differences between the target groups. One of the most important results of the article is the creation of an aggregated settlement quality of life (QOL) indicator. The research observes both objective and subjective factors based on a primary questionnaire survey conducted in 2018 resulting from a sample of 844 respondents. The results are interpreted with crosstab, correlation and variance analysis.

Keywords: quality of life, living space, Balaton, local residents, second homes, QOL indicator

Absztrakt: A tanulmány Magyarország második legfontosabb turisztikai desztinációjával, a Balatonnal foglalkozik, melynek kapcsán életminőség és élettér vizsgálatok kerülnek górcső alá három fókuszcsoport tekintetében; két helyi (ott él és ott dolgozik; ott él, de nem ott dolgozik) és egy második otthonnal rendelkező csoport kapcsán. A szerzők véleménye szerint az életminőséget és az életteret befolyásoló tényezők jobb megértése egyre fontosabb területe a fenntartható turizmusfejlesztésnek és a turizmus menedzsmentnek is. Az eredmények feltárása mellett a tanulmány fő célja a csoportok közötti különbségek megismerése, a tanulmány egyik legfontosabb eredménye pedig, hogy kialakításra került egy ún. aggregált települési életminőség mutató (ATÉM). A kutatás objektív és szubjektív tényezőket is vizsgál, melynek az alapját egy 2018-as, 844 fő bevonásával kivitelezett kérdőíves felmérés adja. Az eredményeket kereszttábla-, korreláció- és varianciaanalízissel mutatjuk be.

Kulcsszavak: életminőség, élettér, Balaton deszináció, helyi lakosság, második otthon tulajdonosok, aggregált települési életminőség indikátor

\section{Highlights}

- The study aims to reveal the evaluation of quality of life (QOL) factors of the local residents and the owners of the second homes from a regional perspective.

- The research observes both objective and subjective factors based on a primary questionnaire survey conducted in 2018 resulting from a sample of 844 respondents.

- One of the most important results of the article is the creation of an aggregated settlement quality of life (QOL) indicator.

\section{Introduction}

The evaluation of quality of life and living space is not just a popular research topic in urban studies, human geography or sociology, but it creates an important research field in tourism researches as well (Kovács et al, 2019). Such researches originate back to the principle idea that a certain geographical space, a settlement or a landscape, means much more than just a simple element of space (Tuan, 1977). The relationship with the home or the place that we call home is the totality of different meanings, opinions, symbols, feelings and values, which are attached to the individual or group of people to a certain location (Flusser, 1996). That is why it is important in quality of life researches to survey what the dwelling place of a certain settlement or region 
means to the local population, how they are connected to the certain settlement and how it influence them in the evaluation of their environment (Jeffres and Dobos, 1993, Andereck and Nyaupane, 2010).

The aim of the article is to present a case study surveying the evaluation of quality of life and living space in the Balaton destination (Hungary) based on the perceptions of the local residents and the owners of second homes on their settlement they live in. With this research, we can achieve results for a better understanding of subjective and objective living factors in the settlements in the analysed region from the perspective of the success or failure in providing adequate QOL factors for the local residents and for the second home owners. The Balaton destination is a traditionally accentuated tourism region of Hungary playing a prioritised and significant role in the tourism industry of the country (Marton and Jónás-Berki, 2013). Within the scope of the domestic tourists, it is the most well-known and visited holiday region of the country and in terms of the foreign visitors, the lake and its surrounding region is the second most popular destination (Aubert and Berki, 2007). The authors believe that the presented results can also contribute to the more successful tourism management of the settlements since the detected QOL factors can influence the decisions of the tourists as well.

The research intends to reveal the reasons why a certain settlement is chosen in the Balaton destination as a place for permanent living and/or for second homes. What are the factors and motivations behind these decisions? We also intend to seek answers how the type of connectedness to a certain settlement influences quality of life and living space evaluation? The research observes both objective and subjective factors with which quality of life and living space can be characterised with an aggregated indicator as well, which might alter taking into consideration the results of the permanent inhabitants and from the ones owning second homes. Our paper reveals these differences and also determines the ranking of the settlements based on quality of life and living space conditions with the help of a cumulated aggregated settlement quality of life indicator. Summing up the aims and objectives, the article's primary aim is to evaluate the quality of life and living space in Balaton area in a complex way. In doing so, it detects the differences between residents working locally, residents not working locally and second home owners, determines the reasons to choose a certain settlement at Lake Balaton as a place for permanent living and/or second home location and determines the impact of the bondage to a certain settlement on quality of life and living space evaluation.

Therefore, the article seeks answers for three main research questions:

RQ1: What is the motivation to choose the location for a dwelling place or for the second home in the Balaton destination?

RQ2: How the type of bond to the settlement of the respondent influences the evaluation of quality of life and living space?

RQ3: Is it possible to scale both objective and subjective characteristics of the quality of life of the settlements in the Balaton destination using one aggregated indicator? Do the values of this aggregated indicator differ between three categories of residents and second home owners?

As research implications, the authors would highlight that such investigations in the Balaton area has not yet been conducted, and we also stress that the methodology and the use of the aggregated settlement quality of life (QOL) indicator developed by the authors is unique in the Hungarian QOL researches related to the settlement aspects and might add further knowledge to the international researches as well. The importance of this study relies on the fact that the results of the present study can be used for both theoretical and practical purposes. In practice, besides the mentioned theoretical implications, this research further deepens the knowledge for decision makers and local government actors in order to better understand the motivations of the local population for living in the certain settlement and gives a detailed feedback on the indicators of QOL that work well or need improvements in the settlement. Moreover, the detected and revealed QOL development level of the settlements presents a detailed feedback on their tourism attraction as well. 


\section{Theoretical background}

\section{Quality of life and living space}

There are numerous approaches to defining quality of life. It is not an easy task to identify and define it, much less measure it. The study of quality of life has long been a major issue covering several academic disciplines (Schuessler and Fisher, 1985). Wong (2006) stated, that despite the different approaches used for identifying, designing, and implementing community indicator systems, they all share a common value of improving the quality of living of people and places (Wong, 2006). According to Brendan, F. et al (2008, pp. 12.) "Quality of Life (QOL) is the extent to which objective human needs are fulfilled in relation to personal or group perceptions of subjective well-being". In the concept system of QOL way of living, life circumstances, lifestyle, life situation and conditions for life are categorized among the objective pillars, while the subjective pillar can also be investigated in a wide context such as satisfaction, hope, happiness, the way you feel and priority (Bruni and Porta, 2007).

Veenhoven (2000) refers to multiple human life qualities, which can be ordered on the basis of two distinctions. The first distinction is between opportunities and the outcomes of life. He explains: "...a relevant distinction is between opportunities for a good life and the good life itself. This is the difference between potentiality and actuality. I refer to this as life chances and life results" (Veenhoven, 2000, pp. 4). The second distinction he makes in defining quality-of-life is between outer and inner qualities of life. The outer quality relates to the environment and the inner to the individual.

Another consideration is the need to look at "community" level quality of life (Budruk and Phillips, 2011, Brankov et al. 2019). Shin (1980) concluded that quality of life at the community level has two dimensions, the first is the level of citizen satisfaction related with various community resources and the second is the distribution of this satisfaction across the citizenry.

According to the categorisation of Utasi (2006) and Michalkó (2010), welfare refers to the objective factors of QOL (income, state of health, technological infrastructure, school maintenance, public security etc.) while well-being refers to the subjective factors (happiness, appreciation, love etc.).

\section{The theoretical background for second homes}

The formation of second homes can be dated back in the 1960s-1970s when the fundamental economic and social changes, together with the technological development, resulted in significant changes in urbanisation and in the life of modern societies (Hall, 2015, Csordás and Juray, 2007, Jaakson, 1986). As Csordás (2020) states, one of the consequences of these structural changes was that the traditional social functions were split in time and space and besides the dwelling spaces, the locations for leisure activities started to acquire an increasing role (Csordás, 2020). Accordingly, in the case of second homes, a social and spatial diffusional process was experienced starting primarily from the cities (urbanisation processes) affecting mainly the suburban, rural and touristic areas (Gallent, 2007, Halfacree, 2012, Raffay-Danyi and Péter, 2019). Fialová et al. (2018) also emphasize that the major stimuli for the emergence of second homes in their researched area (Czechia) was due to the traditional relations to nature and the boom in urbanisation processes (Fialová et al. 2018).

In line with the appearance of this phenomenon, spatial sciences realised the scientific importance of the study of second homes or holiday homes, summer cottages, summer houses or vacation homes as well (Tombaugh, 1968, Ragatz, 1970, Clout, 1972, Dower, 1974). According to Hall (2015), the topic of second homes has been of major interest in regional, rural and tourism planning and policy since the 1970s. In his study, Hall (2015) emphasizes that the great majority of second home research is based in peri-urban, rural and peripheral areas, however, the author argues with these research directions since the "second homes occur unevenly in space and time and are more significant in areas subject to high degrees of tourism urbanisation, such as in coastal and alpine areas" (Hall, 2015). 
Farahani and Mirani (2015) states that there is no single definition of second home and so they refer to Rogers et al. (2013) according to which second home is a "property owned and maintained by a household in addition to its main place of residence, commonly in the form of a "holiday home' or 'weekend retreat'. Such properties are often concentrated in low-density, high-amenity rural areas, and are often thought to compromise the ability of local families to find housing or even lock local economies into patterns of seasonal dependence" (Mirani and Zarani, 2015, Rogers et al., 2013). Agreeing with the definition of Csordás (2020), second homes are such privately owned properties or estates in long-standing use, which serves for the occasional accommodation of such person (family) who does not consider it as his permanent home (Csordás, 2020).

The study of second homes cover a wide range of disciplines, such as economy and business, sociology, tourism, rural and urban studies (Salazar and Zhang, 2013, Fialová and Vagner, 2014, Pitkänen et al. 2014) and trending topics can cover second homes as investment properties, considering its socio-cultural background (Sulyok and Madarász 2019, Rye, 2011), taking into consideration their environmental impacts (Strandell and Hall, 2015) or investigating in identity issues (Fialová et al. 2010, Stedman, 2006).

Due to the development of tourism processes, the phenomenon appeared in the researched destination, at Lake Balaton, in the 1960s and 1970s. The few domestic researches of this topic show that the population appearing in the second homes influence different economic, social and environmental impacts on the settlements so Lake Balaton should be considered as a tourism destination and as a living space in the case of the second home owners (Raffay-Danyi and Péter, 2019).

\section{Quality of life and tourism}

To narrow down on this topic, there are several approaches related to the correlation of $Q O L$ and tourism as well. One the one hand, studies deal with how QOL has an effect on the demand factors, so where is tourism allocated among the components influencing QOL and further on how different social factors (demography, financial state, income) are influencing the positive, happiness increasing function of travelling. On the other hand, the relation system of $Q O L$ and tourism is analysed in terms of the receiving region, from the point of view of the local population (supply). In other words, in what measure do tourism contribute to the QOL of the certain living space and how does it influence the QOL of the local population. The third direction is the measurement of $\mathrm{QOL}$ on tourism and the analysis of the measurement methodology (Michalkó, 2010).

In postmodern societies, since the former separation of work and leisure time decreased, the interpretation of leisure changed as well (Csíkszentmihályi, 2008). Tourism can be typically classified into such activities during which the travellers can go through the flow experience (Michalkó, 2010). This flow experience during travel is equally true to leisure and business type aspects of tourism. Participation in tourism requires a significant preparation and organisation, which, according to some researchers, is, classified into the flow experience as well (Möser and Weiermair, 1998; Bieger and Laesser 2004).

As tourism affects quality of life, the tourist and the local population at the target areas become involved (Uysal et al., 2012). The focus of the research of the impact of tourism on the quality of life of the local population gained momentum in the last two decades considering both international and Hungarian aspects (Andereck and Nyaupane, 2010; Michalkó et al., 2010). In Hungary, Puczkó and Rátz (1998) identified three impact groups (economic, social-cultural and environmental) with important aspects on quality of life from the point of view of the local population (Kovács et al., 2019).

Tourism also actuates the subjective quality of life of the tourists with generally positive aspects through the direct and indirect impacts of travelling (Nawijn, 2010). Direct impacts involve the effect of anticipation before the travel, the effect of the experiences during the travel and the after-effects as well. The acquired experience can indirectly contribute to the happiness level of the every-day life, for instance, by evoking these experiences (Nawijn, 2010). 
In Hungary, the relationship between tourism and quality of life was first emphasized in official planning documents in the National Tourism Development Strategy 2005-2013 (MTH, 2005) and even most recently, the proceeds of this wellbeing-oriented approach can be detected in the National Tourism Development Strategy 2030 (MTÜ, 2017) as well. This latter document emphasized the importance of such supply development, which focus on happiness and shall be realized in the living space of the local population. The strategy underlines the importance of the strengthening of wellbeing, concerning both the tourist and the local population, which shall be fulfilled in the tourism target area and/or the living space of the local population with the development of supply assuring sustainability and taking into consideration carrying capacity (Kiss et al., 2020).

Finally, it is important to mention the model creating endeavours as well. Based on the quality of life factors of Rahman et al. (2005), Puczkó and Smith (2011) established the Budapest model that can be defined both concerning the local population and the tourists as well. This model demonstrates the relation system between tourism and family (social) relations, health, work, material well-being, belonging to somewhere, personal security, environment and emotional wellbeing. The researches based on this model clearly confirmed that tourism actuates most of the life quality factors. The strongest correspondence is related to health, work and productivity, emotional and spiritual well-being and regarding the connections with the family and friends (Kovács et al., 2019).

\section{Methodology}

During the research procedure, the authors formulated the following research questions:

RQ1: What is the motivation to choose the location for a dwelling place or for a second home in the Balaton destination?

RQ2: How the type of bond to the settlement of the respondent influences the evaluation of quality of life and living space?

RQ3: Is it possible to scale both objective and subjective characteristics of the quality of life of the settlements in the Balaton destination using one aggregated indicator? Do the values of this aggregated indicator differ between three categories of residents and second home owners?

In order to answer these research questions, the authors carried out an empirical research. A questionnaire was formulated, which was located online on the questionnaire editing platform of LimeSurvey and the printed version of the questionnaire was also prepared. In order to be able to cover the analysed destination representatively, the completion of the questionnaire was carried out both online and with personal query. The questions were grouped into five categories (the objective indicators of the quality of life of the settlement; the subjective judgement of the quality of life; the judgement of the state of tourism-related enterprises in the settlement; bonding to the locality, the measure of local identity; demographical background). In the present study, the authors review the research results of the first two question groups.

During the research, the total multitude was based on the residents of the 174 settlements of the Balaton region out of which the respondents were chosen by a convenience sampling procedure. The advantage of this method can be found in its simplicity and also that concerning a great sample, it represents the multitude well. Accordingly, our research group members selected settlements within the destination, visited them and asked random people to answer the questions of the questionnaire. Only those people were asked to fill it who were (1) local resident of the visited settlement or (2) second home owners there. In the second round of data collection, we sent the link of the questionnaire to local governments and organisations to spread the online version of the survey among the residents of the destination. Although this method cannot result as a representative sample, it still can be used to explore the basic attitudes and evaluations regarding our topics in the Balaton area (Zawilińska, 2020).

The questionnaire basically included closed questions. There was no need for further coding of the answers, as they were already primarily coded on an ordinal scale in the questionnaire or 
could only be measured on a nominal scale. Quality of life questions were asked on a Likert scale of 1 to 5 and 10, respectively, i.e. the answers were received on an ordinal scale, so no further coding was required.

In order to analyse the above mentioned research questions, during the analysis of the received answers, one-variable and multivariate statistical methods were used alike. The general features of the sample were sized up with descriptive statistics. In the cross-tabulation correlation analysis, derived from the analysis of the nominal scales, the Phi coefficient was used and the Cramer's $V$ association coefficient was also calculated. In order to check the congeniality of the standard deviation of the multiple sample set, the Levene test was used in the applied variance analysis (Malhotra and Simon, 2009; Sajtos and Mitev, 2007; Samuels, 2014).

\section{Introduction to the analysed region}

The Balaton Accentuated Tourism Development Region, impounded by a Government decree (1861/2016. (XII. 27.)), is the most popular destination of the country among the domestic visitors and the second most popular among the foreign visitors. The region covers altogether 174 settlements out of which 42 is allocated directly along the shore (429/2016 (XII. 15.)). The region should not be confused with the Balaton Accentuated Tourism Zone (with 179 settlements), however the overlap between these two regions is dominant, but, for instance, in this case, a county seat (Veszprém) is also involved (2000. CXII. Act) (Figure 1).

Quality of life came into prominence in a growing extent in the latter years since during the urbanisation processes the close-to-nature, more relaxed lifestyle, the slow movements have been valorised (Uysal et al., 2012, Kovács et al., 2019). Lake Balaton and its surroundings is one of the most favourite destinations in Hungary in order to create such way of lifestyle (Lőrincz et al., 2019).

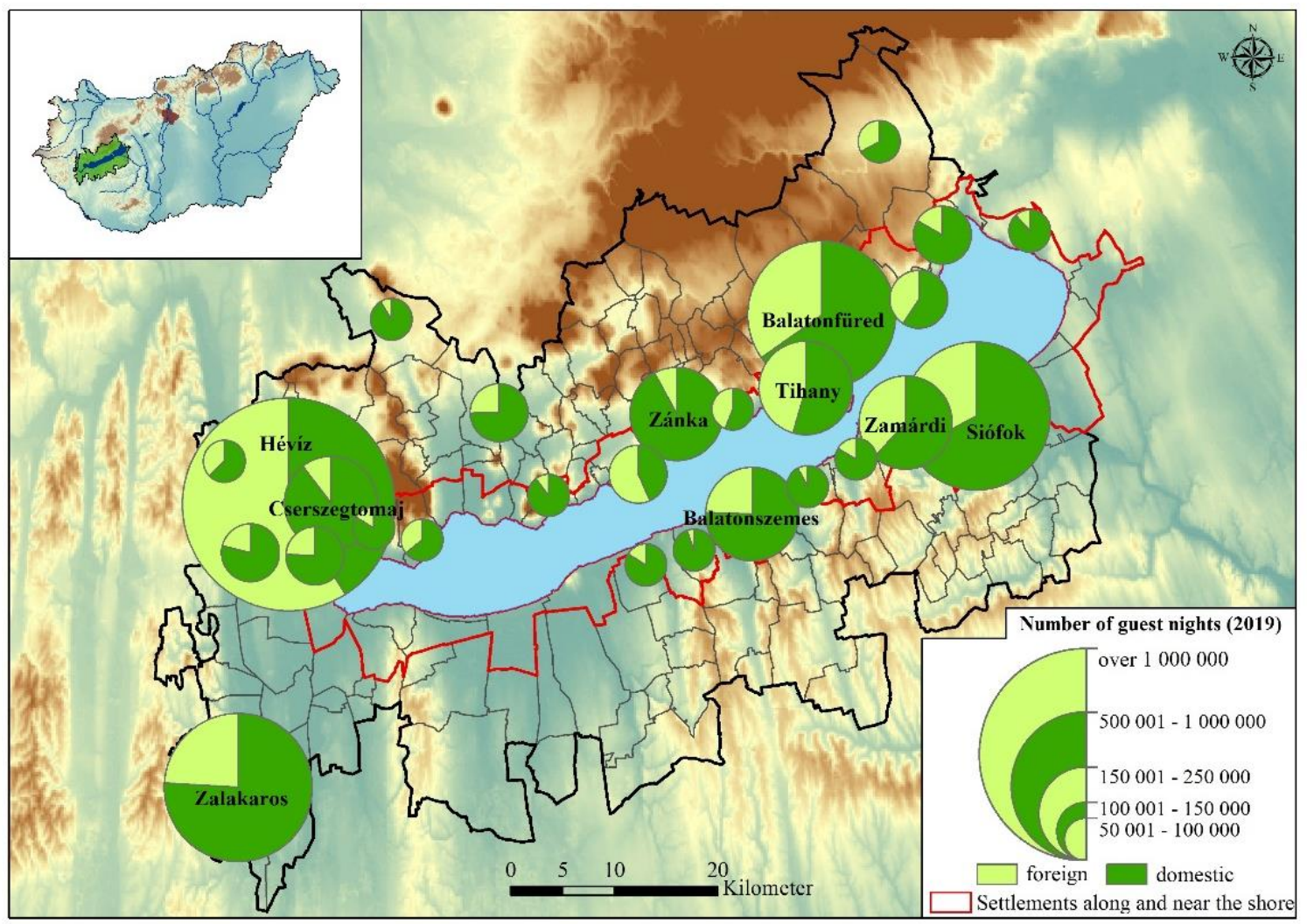

Fig 1. The Balaton Accentuated Tourism Zone and its most important settlements in terms of tourism (2019). Source: own editing

The varied population of the lake (local population, second home owners, tourists) and its surrounding areas claim different expectations and demand, and at the same time forms 
the environment in altering extent (Schleicher, 2018). This is also because the tourism of Lake Balaton is characterised by a duality, namely the congested summer period and the desolate winter period. However, in the last years, the region was making remarkable efforts in order to decrease seasonality, but these efforts are strongly influenced negatively by the climatic determination (Fehérvölgyi and Sulyok, 2017).

The region is characterised by an ageing population and outmigration of the young generations, parallel with the processes of inward migration from urban areas of the country, which segment, originally as second home owners, later (can) become local residents. The newly settled dwellers are characterised by higher education background and better income conditions (Aubert, 2011; Horváth et al., 2018).

As mentioned in the introduction, the Balaton region is the second most popular Hungarian destination after the capital, Budapest (Figure 2). Based on its unique natural and cultural endowments, it has been one of the most popular tourism destinations from a historical perspective as well (Horváth et al., 2018; Rátz and Michalkó, 2007; Sulyok, 2010). In the 2010s, besides the passive waterside tourism activities, such auxiliary tourism products have been strengthened as cultural and festival tourism, health tourism and active tourism, where cycling tourism became the most dominant product (Horváth et al., 2018). The strengthening of these auxiliary products made a growth in the spatial extension of the touristically involved regions, so due to the developments of the last decades, besides the traditional ones, new central regions appeared in the Balaton region (Aubert, 2011; Pálfi et al., 2015; Horváth et al., 2016).

The greatest fresh water lake of Central Europe attracts visitors with a supply oriented to the seasonal changes (Horváth et al., 2018; Sulyok, 2013; Tóth, 2005). Of course, the most important natural attraction is the lake itself where water and waterside tourism are the most important elements of attraction (boating, sailing, bathing, water sports, kayaking, canoeing etc.). There are more than 100 beaches along the shore qualified by the Blue Flag qualification system. The water depth on the northern shore is deeper while in the southern shore is much shallower assuring different physical endowments for the target groups (e.g., families with small children prefer the southern shore more).

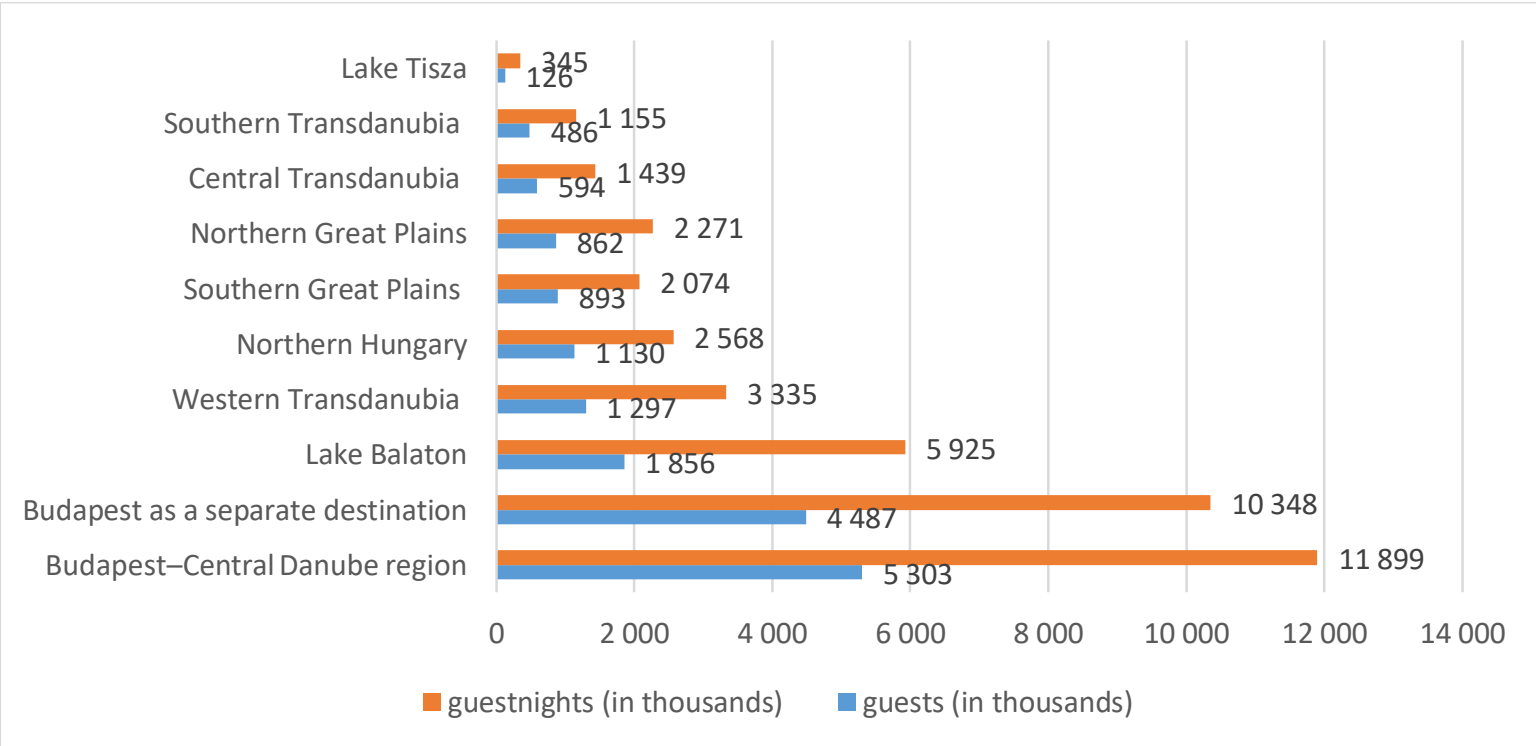

Fig 2. The number of guests and guest nights in the commercial accommodations of the Hungarian tourism regions. Source: Based on HCSO (https://www.ksh.hu/docs/hun/xstadat/xstadat_eves/_oga018.html); own editing

The natural attractions of the lake are complemented with such regions and attractions as the Balaton Highlands National Park (hiking and trekking), the Hévíz curative lake (health tourism, recreation), and the Balaton Cycle Circuit (cycling, jogging, roller skating).

Among the cultural attractions, one should highlight the architectural sites (Benedictine Abbey of Tihany, Festetics Castle in Keszthely, the fortresses in Veszprém, Szigliget and Sümeg), the wine 
regions, wine routes on the northern and southern shore alike (Badacsony, Csopak, Balatonlelle), gastronomy and local products (beach food, local markets), adventure parks (Zalaszabar, Balatonboglár, Balatonfüzfö) and events and festivals (Nagyon Balaton festival series, VeszprémFest, Jazz Piknik, BalatonSound, Művészetek Völgye, Anna Ball of Balatonfüred, Blue Ribbon Race around Lake Balaton).

According to the latest demand statistics, until 2019, the tourism flow of Lake Balaton showed an increasing trend. In 2019 , the destination attracted $16 \%$ of all the guests of the country and $20 \%$ of all the guest nights. It should also be highlighted that $77 \%$ of the guests in the destination were domestic tourists with $68 \%$ of all the guest nights (Figure 3 ). The mean length of stay is 3.07 days (4.27 days for foreign tourists, 2.71 days for domestic tourists) (HCSO).

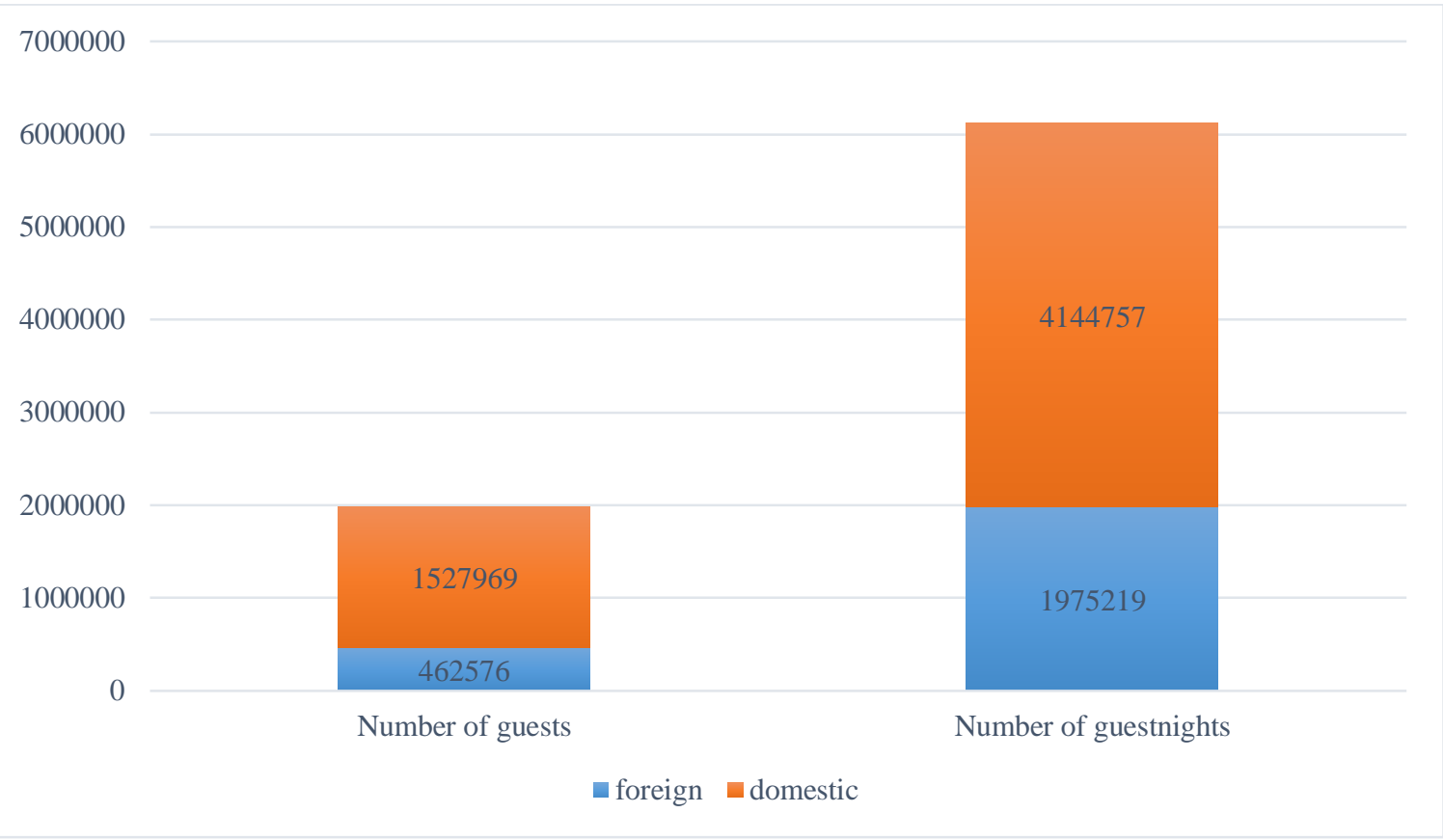

Fig 3. The tourism flow of the Balaton destination in the commercial accommodations, 2019. Source: Based on HSCO (Hungarian Central Statistical Office) database, own editing

In terms of the foreign market, the most important sending regions are Germany (97000 tourists), the Czech Republic (57 000 tourists), Austria (56 900 tourists) and Russia (25 600 tourists). Based on the guest nights, Germany (609 000 guest nights) is followed by Russia (215 000 guest nights), the Czech Republic (207 000 guest nights) and Austria (197000 guest nights).

Based on the upper mentioned introduction, we can state that the level of seasonality is still high in the Balaton region, however, recent trends demonstrated that the supply in the spring and autumn period can be diversified and so the measure of seasonality can be decreased. Based on this product development strategy active tourism, and within that cycling tourism, plays a highlighted role in the region.

\section{Analysis and results}

The questionnaire was filled by 1201 respondents of 83 settlements out of which 1051 proved to be analysable after data cleaning. The total population of the 83 settlements is $262,991(334,201$ in the 174 settlement), which means $0.46 \%$ of the residents filled the questionnaire. Based on the Hungarian Central Statistical Office's data (KSH, 2014) there are 10,839 dwellings in Balaton destination that are occupied seasonally or secondarily. It means that the included 270 second homeowners make up $2.5 \%$ of the total population. During the data cleaning, we checked whether all respondents provided their place of residence and wrote a real postal code. In addition, we filtered out online questionnaires that did not answer essential questions related to the main topic of the research. 
The analysed settlements decently, however not representatively, cover the destination, based on the number of the population and the geographical allocation as well. The quantitative analyses were carried out by SPSS Statistics 23.0 software. Table 1 demonstrates the relevant demographical data of the respondents from which the type of the respondents meant the basis for the latter multivariate analyses.

Tab 1. The major demographic features of the sample. Source: own editing

\begin{tabular}{|c|c|c|c|c|c|c|c|c|}
\hline \multicolumn{3}{|c|}{ Valid $N=923$} & \multicolumn{3}{|l|}{ Valid $\mathrm{N}=1051$} & \multicolumn{3}{|c|}{ Valid $N=924$} \\
\hline Age & $N$ & N\% & Type of respondent & $\mathrm{N}$ & N\% & Gender & $\mathrm{N}$ & $\mathrm{N} \%$ \\
\hline $\begin{array}{l}16-34 \\
y r s \text { of } \\
\text { age }\end{array}$ & 374 & $40.5 \%$ & $\begin{array}{l}\text { Local resident who lives } \\
\text { there habitually and works or } \\
\text { studies there. }\end{array}$ & 594 & $56.5 \%$ & Male & 336 & $36.4 \%$ \\
\hline $\begin{array}{l}35-51 \\
y r s \text { of } \\
\text { age }\end{array}$ & 321 & $34.8 \%$ & $\begin{array}{l}\text { Local resident who lives } \\
\text { there habitually, but works or } \\
\text { studies elsewhere. }\end{array}$ & 187 & $17.8 \%$ & Female & 588 & $63.6 \%$ \\
\hline $\begin{array}{l}52-69 \\
\text { yrs of } \\
\text { age }\end{array}$ & 195 & $21.1 \%$ & $\begin{array}{l}\text { Owns a secondary home or } \\
\text { holiday house at the } \\
\text { settlement. }\end{array}$ & 270 & $25.7 \%$ & & & \\
\hline $70+$ & 33 & $3.6 \%$ & & & & & & \\
\hline
\end{tabular}

First, the paper reveals the results for RQ1: What is the motivation to choose the location for the dwelling place or for the second home in the Balaton destination?

First, we analysed the answers of the respondents who own second homes with simple frequency analysis. Based on this, more than one third (37\%) of the 270 respondents chose the certain settlement for their secondary home/holiday house, based on their bond with family or friends. The second most important motivation (17\%) was that earlier, they had been visiting the settlement and took a liking to it. The third most important motivation was the easy accessibility of the settlement (13\%), followed by their lifestyle as a main motivation ( $8 \%) .20 \%$ of the answers were so diverse that they could not be classified into any group, however one of the most frequently mentioned reasons was inheritance (which was not their own decision as the owner in terms of choosing the settlement) (Figure 4).

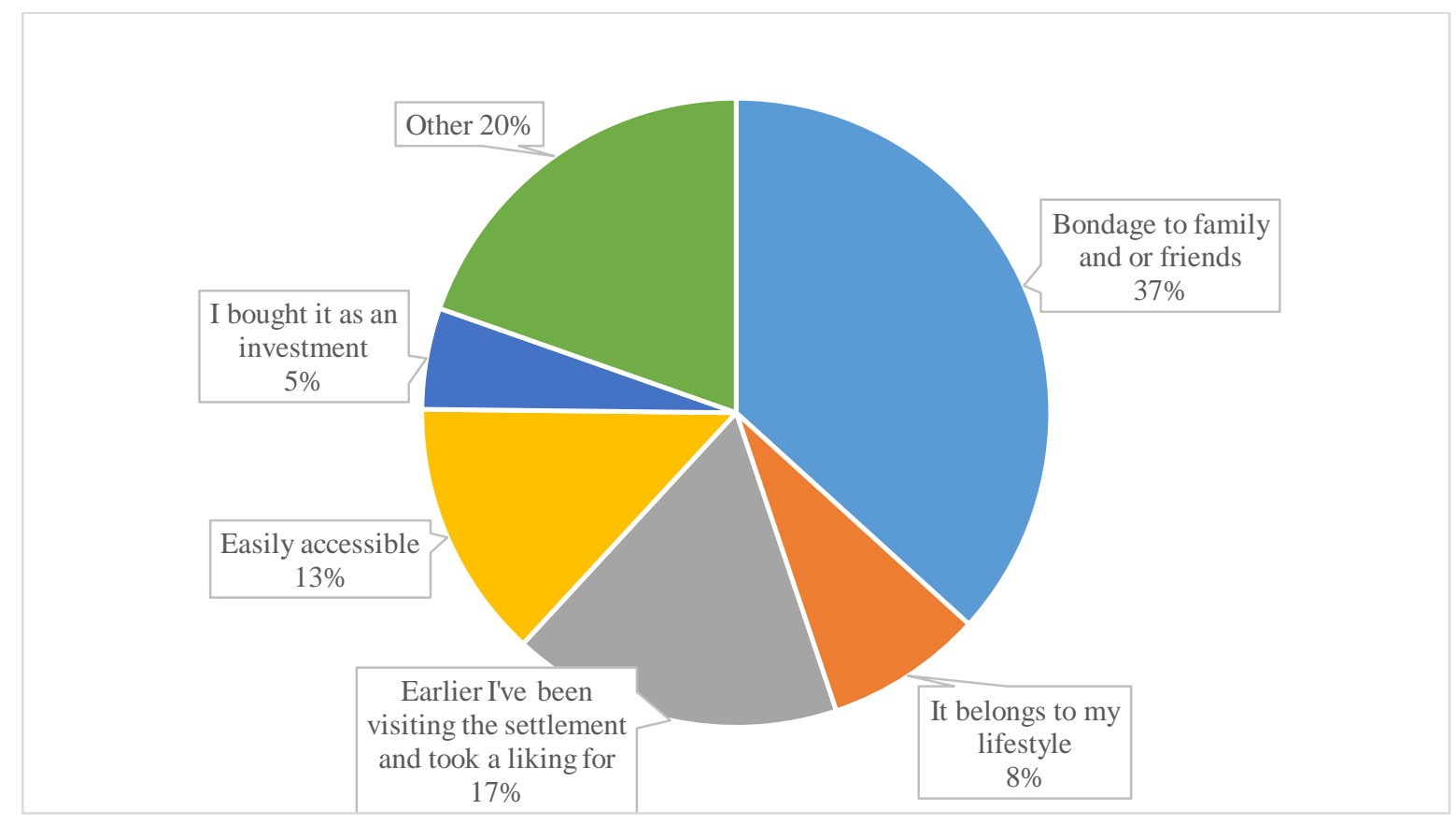

Fig 4. The reasons for choosing the settlement for the second home owners $(N=270)$. Source: own editing 
Since we categorized the local residents into two categories (local resident who lives there habitually and works or studies there and local resident who lives there habitually, but works or studies elsewhere.), in their case, the motivation for the selection of the settlement could be analysed with cross-tabulation as well (Table 2). Figure 5 shows the main data in more visible form.

Tab 2. Analysis of the settlement selection process based on the motivation according to the type of the respondent. Source: own editing

\begin{tabular}{|c|c|c|c|c|c|c|c|c|}
\hline & & \multicolumn{6}{|c|}{ Motivation for choosing the living place } & \multirow[b]{2}{*}{ Total } \\
\hline & & $\begin{array}{l}\text { I was } \\
\text { born } \\
\text { here }\end{array}$ & $\begin{array}{l}\text { A close } \\
\text { relative } \\
\text { lives here }\end{array}$ & $\begin{array}{l}\text { I work } \\
\text { here }\end{array}$ & $\begin{array}{l}\text { I studied } \\
\text { here }\end{array}$ & $\begin{array}{l}\text { I like the } \\
\text { surroundings }\end{array}$ & Other & \\
\hline \multirow{3}{*}{$\begin{array}{l}\text { Lives there habitually } \\
\text { and works/studies there } \\
\text { as well }\end{array}$} & valid cases & 252 & 103 & 54 & 46 & 86 & 52 & 593 \\
\hline & $\begin{array}{l}\% \text { within the } \\
\text { type of the } \\
\text { respondent }\end{array}$ & $42.5 \%$ & $17.4 \%$ & $9.1 \%$ & $7.8 \%$ & $14.5 \%$ & $8.8 \%$ & $100 \%$ \\
\hline & $\begin{array}{l}\% \text { within the } \\
\text { motivation }\end{array}$ & $72.4 \%$ & $74.6 \%$ & $91.5 \%$ & $88.5 \%$ & $72.3 \%$ & $81.3 \%$ & $76.0 \%$ \\
\hline \multirow{3}{*}{$\begin{array}{l}\text { Lives there habitually } \\
\text { but works/studies } \\
\text { elsewhere }\end{array}$} & valid cases & 96 & 35 & 5 & 6 & 33 & 12 & 187 \\
\hline & $\begin{array}{l}\% \text { within the } \\
\text { type of the } \\
\text { respondent }\end{array}$ & $51.3 \%$ & $18.7 \%$ & $2.7 \%$ & $3.2 \%$ & $17.6 \%$ & $6.4 \%$ & $100 \%$ \\
\hline & $\begin{array}{l}\% \text { within the } \\
\text { motivation }\end{array}$ & $27.6 \%$ & $25.4 \%$ & $8.5 \%$ & $11.5 \%$ & $27.7 \%$ & $18.8 \%$ & $24.0 \%$ \\
\hline \multirow{3}{*}{ Total } & valid cases & 348 & 138 & 59 & 52 & 119 & 64 & 780 \\
\hline & $\begin{array}{l}\% \text { within the } \\
\text { type of the } \\
\text { respondent }\end{array}$ & $44.6 \%$ & $17.7 \%$ & $7.6 \%$ & $6.7 \%$ & $15.3 \%$ & $8.2 \%$ & $100 \%$ \\
\hline & $\begin{array}{l}\% \text { within the } \\
\text { motivation }\end{array}$ & $100 \%$ & $100 \%$ & $100 \%$ & $100 \%$ & $100 \%$ & $100 \%$ & $100 \%$ \\
\hline value & \multirow{2}{*}{\multicolumn{3}{|c|}{ Phi indicator }} & 0.146 & \multirow{2}{*}{\multicolumn{3}{|c|}{ CramerV }} & 0.146 \\
\hline sign & & & & 0.005 & & & & 0.005 \\
\hline
\end{tabular}

It turns out from the results that among those who live there habitually but work/study elsewhere, there is $9 \%$ more who live in the certain settlement because they were born there and still live there $(51.3 \%$ and $42.5 \%)$. It derives from the categorisation of the respondents that out of the ones from the first group (local resident who lives there habitually and works or studies there), typically more indicated that they chose the certain settlement as living space because they work nearby and they considered it practical to choose their dwelling place near to their workplace. There is no significant difference between the two groups in terms of the frequency of the second most frequent motivation (a close relative/my partner lives in the settlement, that is why I moved here) $(17.4 \%$ and $18.7 \%)$. Among the respondents who live in the certain settlement and work there as well, there are more residents who chose their settlement as a location for their studies as well, while those who live in the certain settlement but work elsewhere, characteristically gave the reason that they live in the settlement because they liked the surroundings so they moved there.

In order to confirm the existence of the relations, $\mathrm{Khi}^{2}$ was used in the analysis of the correspondence between the analysed variables, which confirmed the existence of correspondence between them, since its $p$-value $(p=0.005)$ remained under the admissible 0.05 level. Table 2 contains the indicators (Phi and CramerV indicator) reflecting the strength of these relations based on which one can determine that there is a weak significant relation between the type of the respondent and the motivation for choosing the location as a living place. 


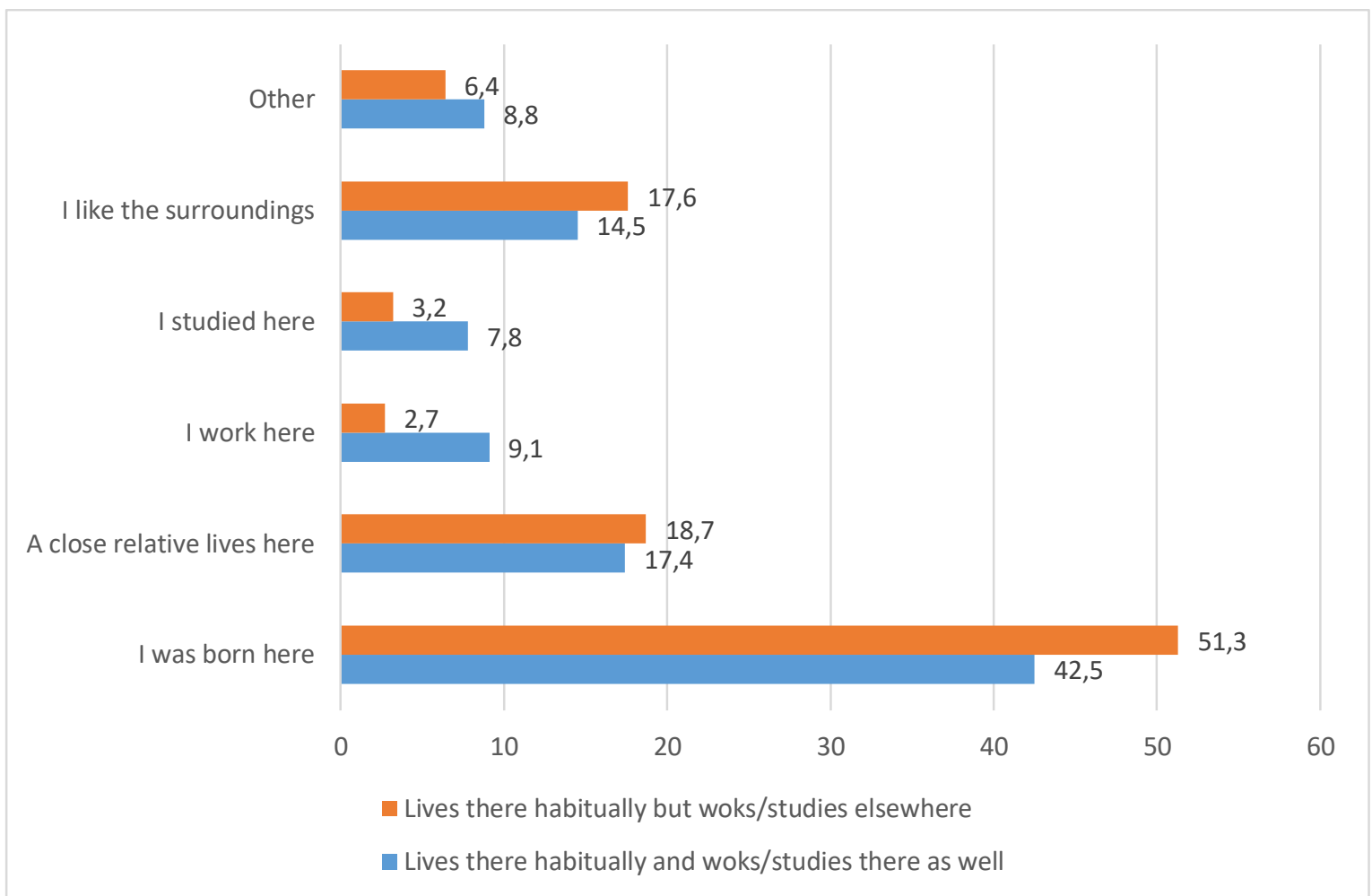

Fig 5. Analysis of the settlement selection process based on the motivation according to the type of the respondent (\%). Source: own editing

By finding the results for RQ2 (How the type of bond to the settlement of the respondent influences the evaluation of quality of life and living space?) we provided answers for which indicators are characterising the certain groups of the respondents in terms of complacency and also how the evaluation of the quality of life indicators differ in the certain groups of the respondents.

In the questionnaire, the authors analysed the quality of life in 2 categories: taking into consideration the objective quality of life of 27 indicators, which were chosen based on the professional literature (Piskóti et al., 2012), were evaluated by the respondents and concerning the subjective quality of life a further 9 indicators. In case of the objective factors, the respondents had to indicate their satisfaction level on a $1-5$ scale where 1 meant the least unsatisfied answer and 5 the most satisfied one. In case of the subjective quality of life factors, the respondents had to evaluate the indicators on a $1-10$ scale, where 1 meant totally dissatisfied and 10 meant completely satisfied. In order to determine the differences between the groups, variance analysis was used at both categories.

The authors analysed objective and subjective indicators separately. The reason behind this method is that these two groups were measured on different scales and first we wanted to measure the differences separately. Satisfaction with objective quality of life elements could be indicated on a five-point scale. Objective indicators consist of components that can be easily quantified and measured. However, subjective indicators are more difficult to express and evaluate. These are about personal feelings of respondents, therefore the researchers considered to give respondents the opportunity to express them on a ten-point scale. Furthermore, the authors assumed the possibility that the objective and subjective assessment of a settlement could be independent from each other.

Where the authors found significant differences among the group averages, the differences between the exact groups were mapped with the Scheffé's proof post-hoc test. The Sheffé's proof seems to be the most conservative and so the most reliable proof (Sajtos and Mitev, 2007). The existence of homogeneity standard deviation was analysed with Levente test. In 6 cases, heteroscedasticity was detected but the $\mathrm{F}$ proof, which was used in the variance analysis, is quite a robust proof, so in other words, heteroscedasticity will not necessarily lead to distorted $F$ values (Sajtos and Mitev, 2007). 
Tab 3. The deviations of the objective settlement evaluating factors among the certain groups of the respondents. Source: Own editing

\begin{tabular}{|c|c|c|c|c|c|c|}
\hline Factors & $F$ value & Sign. & & & $\begin{array}{l}\text { Mean } \\
\text { deviation }\end{array}$ & Sign. \\
\hline \multirow[t]{2}{*}{$\begin{array}{l}\text { Parking } \\
\text { opportunities }\end{array}$} & \multirow[t]{2}{*}{9.699} & \multirow[t]{2}{*}{0.000} & $\begin{array}{l}\text { Lives and works/studies in } \\
\text { the settlement }\end{array}$ & $\begin{array}{l}\text { Lives in the settlement but } \\
\text { works/studies elsewhere }\end{array}$ & -0.262 & 0.021 \\
\hline & & & $\begin{array}{l}\text { Lives and works/studies in } \\
\text { the settlement }\end{array}$ & Owns a second home & -0.347 & 0.000 \\
\hline $\begin{array}{l}\text { Traditions, history of } \\
\text { the settlement }\end{array}$ & 8.085 & 0.000 & $\begin{array}{l}\text { Lives and works/studies in } \\
\text { the settlement }\end{array}$ & Owns a second home & 0.281 & 0.001 \\
\hline \multirow[t]{2}{*}{$\begin{array}{l}\text { Supply with public } \\
\text { institutions }\end{array}$} & \multirow[t]{2}{*}{17.256} & \multirow[t]{2}{*}{0.000} & $\begin{array}{l}\text { Lives and works/studies in } \\
\text { the settlement }\end{array}$ & $\begin{array}{l}\text { Lives in the settlement but } \\
\text { works/studies elsewhere }\end{array}$ & 0.215 & 0.026 \\
\hline & & & $\begin{array}{l}\text { Lives and works/studies in } \\
\text { the settlement }\end{array}$ & Owns a second home & 0.432 & 0.000 \\
\hline $\begin{array}{l}\text { Educational } \\
\text { institutions }\end{array}$ & 6.260 & 0.002 & $\begin{array}{l}\text { Lives and works/studies in } \\
\text { the settlement }\end{array}$ & Owns a second home & 0.305 & 0.006 \\
\hline \multirow[t]{2}{*}{$\begin{array}{l}\text { Shopping } \\
\text { opportunities }\end{array}$} & \multirow[t]{2}{*}{6.425} & \multirow[t]{2}{*}{0.002} & $\begin{array}{l}\text { Lives and works/studies in } \\
\text { the settlement }\end{array}$ & $\begin{array}{l}\text { Lives in the settlement but } \\
\text { works/studies elsewhere }\end{array}$ & 0.340 & 0.002 \\
\hline & & & $\begin{array}{l}\text { Lives in the settlement but } \\
\text { works/studies elsewhere }\end{array}$ & Owns a second home & -0.272 & 0.044 \\
\hline $\begin{array}{l}\text { Favourable prices } \\
\text { of real estates }\end{array}$ & 4.334 & 0.013 & $\begin{array}{l}\text { Lives and works/studies in } \\
\text { the settlement }\end{array}$ & Owns a second home & -0.294 & 0.013 \\
\hline Work opportunities & 7.761 & 0.000 & $\begin{array}{l}\text { Lives and works/studies in } \\
\text { the settlement }\end{array}$ & $\begin{array}{l}\text { Lives in the settlement but } \\
\text { works/studies elsewhere }\end{array}$ & 0.368 & 0.002 \\
\hline \multirow[t]{3}{*}{$\begin{array}{l}\text { Recreation } \\
\text { opportunities }\end{array}$} & \multirow[t]{3}{*}{20.510} & \multirow[t]{3}{*}{0.000} & $\begin{array}{l}\text { Lives and works/studies in } \\
\text { the settlement }\end{array}$ & $\begin{array}{l}\text { Lives in the settlement but } \\
\text { works/studies elsewhere }\end{array}$ & 0.247 & 0.028 \\
\hline & & & $\begin{array}{l}\text { Lives and works/studies in } \\
\text { the settlement }\end{array}$ & Owns a second home & -0.404 & 0.000 \\
\hline & & & $\begin{array}{l}\text { Lives in the settlement but } \\
\text { works/studies elsewhere }\end{array}$ & Owns a second home & -0.652 & 0.000 \\
\hline \multirow[t]{2}{*}{$\begin{array}{l}\text { Entertainment } \\
\text { opportunities }\end{array}$} & \multirow[t]{2}{*}{16.538} & \multirow[t]{2}{*}{0.000} & $\begin{array}{l}\text { Lives and works/studies in } \\
\text { the settlement }\end{array}$ & $\begin{array}{l}\text { Lives in the settlement but } \\
\text { works/studies elsewhere }\end{array}$ & 0.466 & 0.000 \\
\hline & & & $\begin{array}{l}\text { Lives in the settlement but } \\
\text { works/studies elsewhere }\end{array}$ & Owns a second home & -0.689 & 0.000 \\
\hline $\begin{array}{l}\text { Range of cultural } \\
\text { programmes }\end{array}$ & 7.916 & 0.000 & $\begin{array}{l}\text { Lives and works/studies in } \\
\text { the settlement }\end{array}$ & $\begin{array}{l}\text { Lives in the settlement but } \\
\text { works/studies elsewhere }\end{array}$ & 0.364 & 0.000 \\
\hline $\begin{array}{l}\text { Quantity and quality } \\
\text { of sightseeing }\end{array}$ & 7.186 & 0.001 & $\begin{array}{l}\text { Lives and works/studies in } \\
\text { the settlement }\end{array}$ & $\begin{array}{l}\text { Lives in the settlement but } \\
\text { works/studies elsewhere }\end{array}$ & 0.332 & 0.001 \\
\hline \multirow[t]{2}{*}{$\begin{array}{l}\text { Restaurants, } \\
\text { catering }\end{array}$} & \multirow[t]{2}{*}{7.687} & \multirow[t]{2}{*}{0.000} & $\begin{array}{l}\text { Lives and works/studies in } \\
\text { the settlement }\end{array}$ & $\begin{array}{l}\text { Lives in the settlement but } \\
\text { works/studies elsewhere }\end{array}$ & 0.346 & 0.001 \\
\hline & & & $\begin{array}{l}\text { Lives in the settlement but } \\
\text { works/studies elsewhere }\end{array}$ & Owns a second home & -0.312 & 0.010 \\
\hline \multirow{2}{*}{$\begin{array}{l}\text { Ethnic and age } \\
\text { structure of the } \\
\text { population }\end{array}$} & \multirow[t]{2}{*}{5.855} & \multirow[t]{2}{*}{0.003} & $\begin{array}{l}\text { Lives and works/studies in } \\
\text { the settlement }\end{array}$ & $\begin{array}{l}\text { Lives in the settlement but } \\
\text { works/studies elsewhere }\end{array}$ & 0.275 & 0.10 \\
\hline & & & $\begin{array}{l}\text { Lives in the settlement but } \\
\text { works/studies elsewhere }\end{array}$ & Owns a second home & -0.339 & 0.008 \\
\hline $\begin{array}{l}\text { Friendliness of the } \\
\text { population }\end{array}$ & 4.757 & 0.009 & $\begin{array}{l}\text { Lives in the settlement but } \\
\text { works/studies elsewhere }\end{array}$ & Owns a second home & -0.296 & 0.009 \\
\hline
\end{tabular}

Table 3 and Figure 6 contain only those elements out of the analysed 27 objective quality of life factors, which proved deviation during our analysis. Based on the data, we can assume that the deviation is significant in connection with the satisfaction with the settlement factors overall in the case of 14 factors, altogether in 22 pair-wise comparisons. The respondents living in the certain settlement but working elsewhere are, except for the prices of the real estates, more satisfied than the ones living and working in the settlement. The respondents owning a second home evaluate more positively in every case their satisfaction with the settlement factors than the ones living in the settlement but working somewhere else. Summing up, we can state that, related to the objective settlement factors, in terms of those indicators where the satisfaction level of the 3 groups of respondents significantly differ, the satisfaction level of the ones living in 
the settlement but working elsewhere is the lowest, while the ones living and working in the settlement and the ones owning second homes provided more positive evaluations (in many cases with very close results to each other).

It can also be revealed that the greatest difference appeared in the case of the evaluation of the entertainment and recreational opportunities: in both cases between the ones living in the settlement but working elsewhere and the ones owning second homes.

A variance analysis has also been carried out for the 9 factors influencing the subjective quality of life, but in this case the condition of homogeneity standard deviation has been realized for all the elements. Out of the analysed elements, we found significant alterations in 5 cases (Figure 7). In the case of the factors influencing the subjective quality of life, the least satisfied are the respondents who live and work at the same settlement, while the ones owning second homes are the most satisfied ones. The respondent group of the ones living in the settlement but working elsewhere can be found in between the two previously mentioned groups, except for the general satisfaction level with the settlement, since here the second home owners are even less satisfied than the ones living and working at the settlement. The greatest difference was detected in the case of the satisfaction level with the education level, where the second home owners are significantly more satisfied than the 2 groups of the local population education level appears twice on the figure to show pair differences).

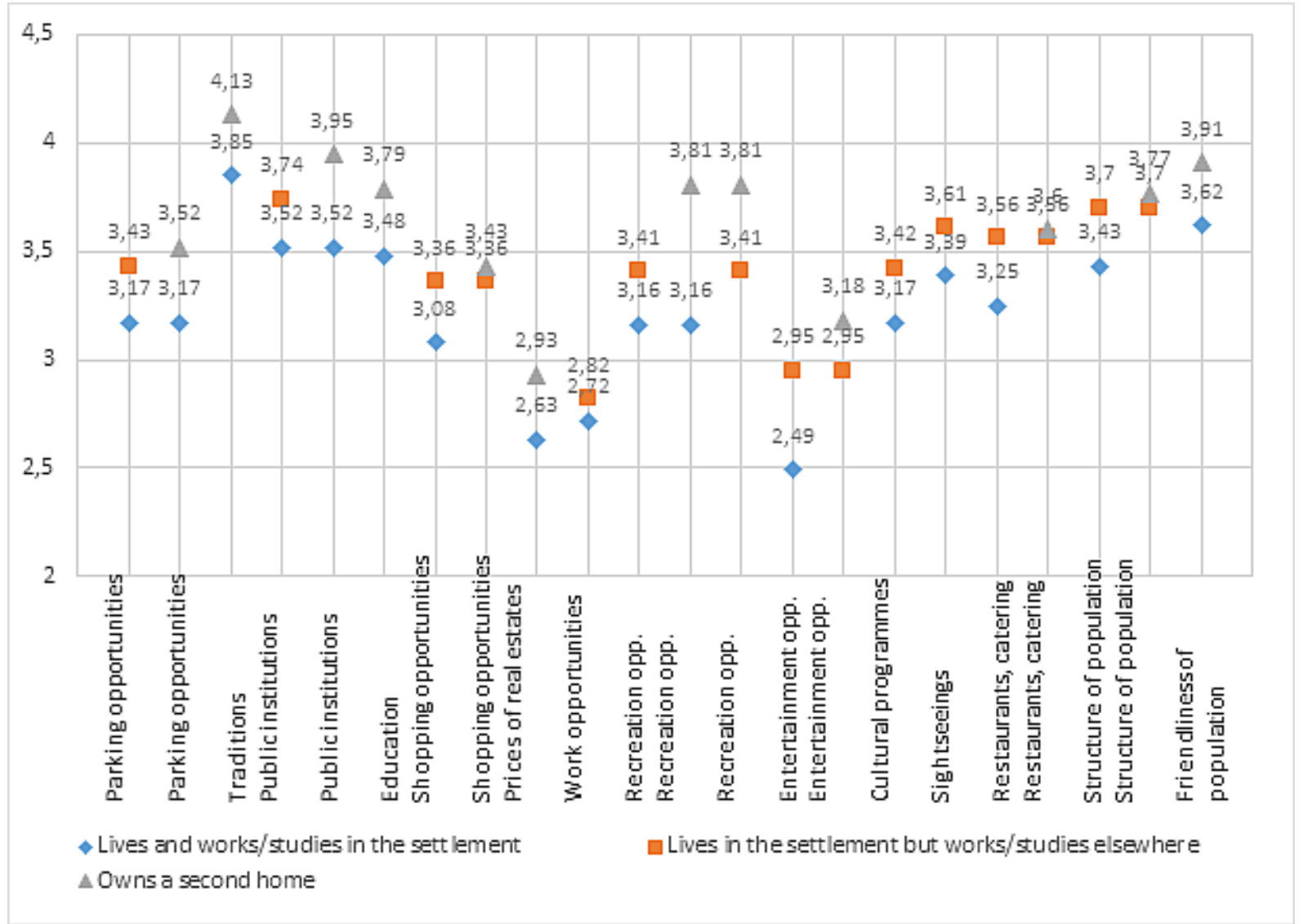

Fig 6. Significant differences in mean per pair by type of respondents in objective elements. Source: own editing 
Tab 4. Statistical characteristics of deviations of the subjective settlement evaluating factors among the certain groups of the respondents. Source: Own editing

\begin{tabular}{|l|l|l|l|l|l|l|}
\hline Factor & F value & Sign. & & & $\begin{array}{l}\text { Mean } \\
\text { deviation }\end{array}$ & Sign. \\
\hline $\begin{array}{l}\text { Financial } \\
\text { circumstances }\end{array}$ & 7.613 & 0.001 & $\begin{array}{l}\text { Lives and works/studies in } \\
\text { the settlement }\end{array}$ & Owns a second home & -0.513 & 0.001 \\
\hline State of health & 3.565 & 0.029 & $\begin{array}{l}\text { Lives and works/studies in } \\
\text { the settlement }\end{array}$ & $\begin{array}{l}\text { Lives in the settlement but } \\
\text { works/studies elsewhere }\end{array}$ & -0.394 & 0.030 \\
\hline Education level & 11.538 & 0.000 & $\begin{array}{l}\text { Lives and works/studies in } \\
\text { the settlement }\end{array}$ & Owns a second home & -0.731 & 0.000 \\
\cline { 2 - 7 } & $\begin{array}{l}\text { Lives in the settlement but } \\
\text { works/studies elsewhere }\end{array}$ & Owns a second home & -0.708 & 0.002 \\
\hline $\begin{array}{l}\text { Present living } \\
\text { conditions }\end{array}$ & 5.259 & 0.005 & $\begin{array}{l}\text { Lives and works/studies in } \\
\text { the settlement }\end{array}$ & Owns a second home & -0.463 & 0.006 \\
\hline $\begin{array}{l}\text { Satisfaction with the } \\
\text { settlement on the } \\
\text { whole }\end{array}$ & 3.840 & 0.022 & $\begin{array}{l}\text { Lives in the settlement but } \\
\text { works/studies elsewhere }\end{array}$ & Owns a second home & -0.506 & 0.024 \\
\hline
\end{tabular}

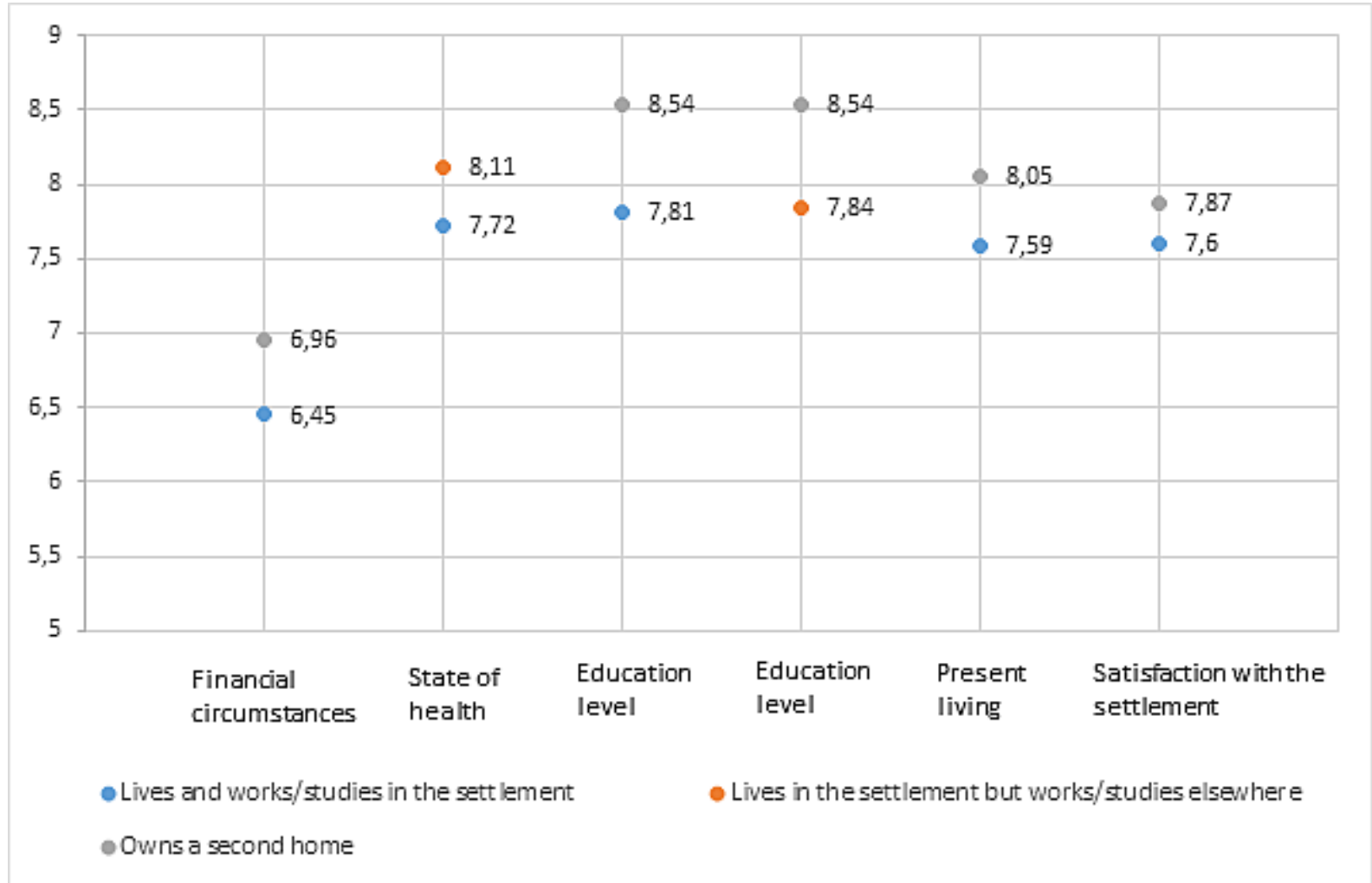

Fig 7. Significant differences in mean per pair by type of respondents in subjective elements. Source: own editing

After the analysis of the objective and subjective factors, our third research question intended to reveal whether it is possible to characterise the quality of life of the settlements in the Balaton destination with one aggregated indicator, and if yes, are the differences demonstrable among the different group of respondents or not.

In order to reveal this research question, the authors analysed separately whether the objective and subjective components can be cumulated or not. In the case of the 27 objective factors, the value of the Cronbach's alpha showing the scale reliability was 0.910 and in the case of the subjective elements, it was 0.836 , so it was proved that the accumulated scale can be prepared at both indicator groups.

Considering that the objective and subjective quality of life factors have been surveyed in different scales, in order to cumulate them, they had to be standardised. After the standardisation, 
the authors investigated the cumulation of the scale elements and found that the 36 elements can be cumulated to 1 variable since the value of the Cronbach's alpha was 0.913 , showing a high level of reliability. After the cumulation, another variance analysis was carried out in order to reveal the alterations between the settlement quality of life indicators and the types of the respondents. As a result of this, it was demonstrated that besides a 2.209 $\mathrm{F}$ indicator a $p=0.110$ significance value was received, so after the cumulation of the variables, no significant alterations were found among the 3 group of respondents.

Henceforth, with the help of the aggregated settlement quality of life indicator, the cumulated objective indicators and the cumulated subjective indicators, the top 10 list of the analysed settlements was determined (Table 5). Based on the aggregated settlement quality of life indicator, the settlements were categorised into 3 categories. Regarding that our aggregated indicator is based on standardised values, the authors created the following categories: liveable QOL places (settlements with average values, where the indicator is between -0.1 and 0.1 ), attractive QOL places (settlements with above average values, where the indicator is above -0.1) and lagging QOL places (settlements under the average values, where the indicator is under - 0.1$)$. The certain categories covered nearly one third of the whole number of settlement $(27.3 \%$, $36.4,36.4 \%$ ) (Figure 8).

Tab 5. The top 10 settlements of the Balaton region based on the aggregated settlement quality of life indicator. Source: own editing

\begin{tabular}{|l|l|l|l|l|l|l|}
\hline & \multicolumn{2}{|c|}{$\begin{array}{c}\text { Based on objective } \\
\text { indicators }\end{array}$} & \multicolumn{2}{c|}{$\begin{array}{c}\text { Based on subjective } \\
\text { indicators }\end{array}$} & \multicolumn{2}{c|}{$\begin{array}{c}\text { Based on the cumulative settlement } \\
\text { QOL indicator }\end{array}$} \\
\hline & Settlement & Value & Settlement & Value & Settlement & Value \\
\hline 1. & Andocs & 1.2123 & Zalaszántó & 0.9288 & Zalaszántó & 0.5694 \\
\hline 2. & Dörgicse & 0.6752 & Lesenceistvánd & 0.8012 & Lesenceistvánd & 0.5036 \\
\hline 3. & Hévíz & 0.6027 & Balatonszölös & 0.7668 & Gyenesdiás & 0.5001 \\
\hline 4. & Gyenesdiás & 0.5046 & Nemesvita & 0.633 & Nemesvita & 0.4942 \\
\hline 5. & Zalaszántó & 0.4496 & Paloznak & 0.5484 & Balatonszölös & 0.4707 \\
\hline 6. & Nemesvita & 0.4479 & Felsöörs & 0.5168 & Hévíz & 0.385 \\
\hline 7. & Balatongyörök & 0.4212 & Ábrahámhegy & 0.5166 & Hegyesd & 0.379 \\
\hline 8. & Eplény & 0.3611 & Hegyesd & 0.5069 & Eplény & 0.3739 \\
\hline 9. & Alsóörs & 0.3583 & Tótvázsony & 0.5059 & Zamárdi & 0.3427 \\
\hline 10. & Balatonszölös & 0.3496 & Gyenesdiás & 0.4471 & Felsöörs & 0.338 \\
\hline
\end{tabular}




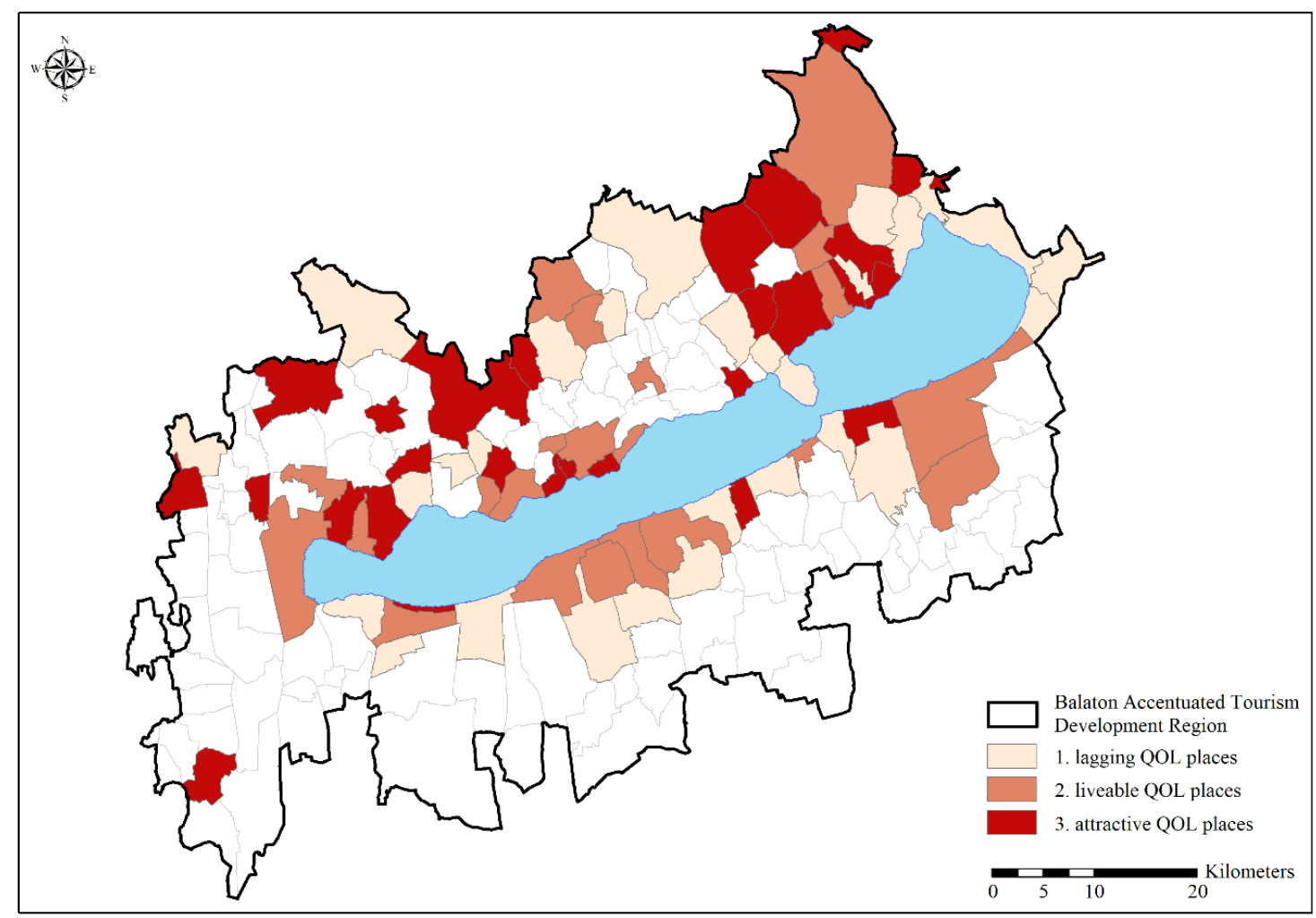

Fig 8. The spatial allocation of the 3 settlement categories based on the aggregated settlement quality of life indicator. Source: own editing

\section{Conclusion and Discussion}

In connection with the first research question, we can conclude that in the case of all the respondent type, the family bond plays the most important role (Second home owners: $37 \%$; Lives and works/studies in the settlement: $42.5 \%$; Lives in the settlement but works/studies elsewhere: $51.3 \%$ ) in choosing a dwelling place or a second home. The motivation of becoming fond of a settlement due to earlier visits (and so settle to buy a house there) plays nearly the same amount of ratio (Second homeowners 17\%; Lives and works/studies in the settlement: 14.5\%; Lives in the settlement but works/studies elsewhere: 17.6\%) concerning all the respondent types. The motivation "I was born in this settlement and live here ever since" appears at more than half $(51.3 \%)$ of the ones living in the settlement but working elsewhere. This information carries such an important content that there might be a lack of workplaces in the certain settlement and also that there is a threat of moving away from there.

Based on the answers of the second research question, we can state that by the relation of the respondents towards the settlement, one can find significant alterations at numerous indicators. Out of the analysed 36 indicators (27 objective settlement evaluation aspects and 9 subjective quality of life evaluation aspects), the satisfaction level of the respondents differs in 19 cases ( 14 objective and 5 subjective elements).

Revealing the reasons of these difference could indicate new directions of this research and at the same time, it raises the attention on the fact that the local citizens and the second home owners, living at the same settlement, can have different judgement on the settlement aspects. According to this, after more detailed analyses, it might be worth to develop the settlements based on target group specific aspects as well.

Regarding the third research question, from the objective and subjective QOL indicators, the authors created a new, cumulated settlement QOL indicator and analysed which settlements produce the highest qualification (settlement ranking). During the evaluation process, it turned out that the top 10 settlements assessment of the objective and subjective indicators differ significantly from each other. It means that in case of objective dissatisfaction, the respondent 
can judge his/her quality of life better or besides an objective satisfaction, one can feel that he/she lives an unsatisfactory quality of life. It is also an interesting result that no such well known and greater places of the Balaton destination were included in the top list as Siófok, Balatonfüred, Keszthely, Veszprém or Sümeg.

One of the limitations of the research is that it lacks complete representativeness, however, based on the great number of sample elements and the applied methodology, the authors believe that the results can be published with interest towards the scientific audience. In the future researches, it is worth considering why the greater settlements of the region, based on the judgement of the respondents, were not included in the top 10 list of the cumulative evaluation. It is also important to better understand how the objective and subjective QOL elements influence each other and also how the bond towards the settlement influence the final settlement ranking in case of the certain indicators.

According to the practical implications of the study, we need to emphasize that we can find the intention of improving life quality on the top of the objective pyramid of the Hungarian tourism development documents (taking into consideration the tourists, the ones employed in tourism and the local community). Our research results contributed to this paradigm change as well, since earlier tourism development policy was rather GDP focused. The authors believe that the results of this article contributed and strengthened the international and domestic trend of the changing consumer habits in tourism, namely the increasing need towards high quality living space and domestic destinations.

The statistical correlations between the type of residents and their quality of life elements point out critical element to be developed depending on which target group we want to make the settlement attractive. Based on the results of the research, detailed proposals can be made to the local governments on the characteristics of the settlement that should be developed.

The most important theoretical implication is that the authors introduced new approaches in the quantitative research of quality of life and living space concerning tourism and so surveyed a region where no such comprehensive researches have been carried out. As methodological novelty, we think that one of the most important results of the article is the creation of an aggregated settlement quality of life (QOL) indicator which method can be used in further region-focused QoL researches as well.

\section{Acknowledgement}

We acknowledge the financial support of Széchenyi 2020 under the EFOP-3.6.1-16-2016-00015.

Academic references

[1] Andereck, K. L. \& Nyaupane, G. P. (2010). Exploring the Nature of Tourism and Quality of Life Perceptions among Residents. Journal of Travel Research, 50(3), 248-260. DOI: $10.1177 / 0047287510362918$.

[2] Aubert, A. (2011). A Balaton a magyar idegenforgalomban. Geographia Pannonica Nova, 11, 81-92.

[3] Aubert, A. \& Berki, M. (2007). A nemzetközi és a hazai turizmus területi folyamatai, piaci tendenciái a globalizáció korában. Földrajzi Közlemények, 55, 119-131.

[4] Bieger, T. \& Laesser, Ch. (2004). Information sources for travel decisions: toward a source process model. Journal of Travel Research, 4, 328-437. DOI: 10.1177/0047287504263030.

[5] Brankov, J., Glavonjić, T. J., Pešić, A. M., Petrović, M. D. \& Tretiakova, T. N. (2019). Residents' Perceptions of Tourism Impact on Community in National Parks in Serbia, European Countryside, 11(1), 124-142. DOI: 10.2478/euco-2019-0008.

[6] Bruni, I. \& Porta, P. (2007). Handbook on the economics of happiness. Cheltenham: Edward Elgar. 
[7] Budruk, M. \& Phillips, R. (2011). Quality of life community indicators for parks recreation and tourism management. Amsterdam: Springer.

[8] Clout, H. D. (1972). Second Homes in the United States. Tijdschrift voor Economische en Sociale Geografie. 63(6), 393-401. DOI: 10.1111/j.1467-9663.1972.tb01185.x.

[9] Csikszentmihályi, M. (2008). Flow: The Psychology of Optimal Experience. New York, NY: HarperCollins.

[10] Csordás, L. \& Juray, T. (2007). A második otthonok mint térformáló tényezők. Földrajzi Közlemények, 3, 187-201.

[11] Csordás, L. (2020). A második otthonok kialakításának okai, fázisai, helyszínei az ipari forradalom korától. GRADUS, 7(2), 297-303.

[12] Dower, M. (1974). Second Homes in Great Britain. In Bulletin, International Federation for Housing and Planning (pp. 31-46). Columbus: Ohio State University.

[13] Farahani, B. \& Mirani, S. Z. (2015). Second homes tourism and sustainable rural development in all around the world. International Journal of Leisure and Tourism Marketing. 4, 176-188. DOI: 10.1504/IJLTM.2015.072076.

[14] Fialová, D., Vágner, J. \& Kůsová, T. (2018). Second homes, their users, and relations to the rural space and the resident communities in Czechia. In Hall, C. M., Müller D. K., eds., The Routledge Handbook of Second Homes Tourism and Mobilities (pp. 222-232). London: Routledge.

[15] Fialová, D. \& Vágner, J. (2014). The owners of second homes as users of rural space in Czechia. Acta Universitatis Carolinae. Geographica. 49(2), 21-38. DOI: 10.14712/23361980.2014.11.

[16] Fehérvölgyi, B. \& Sulyok. J. (2017). Nyitott Balaton - A turisztikai vendégforgalom szezonalitásának enyhítése a Balatonnál. In Árva, L., Deli-Gray, Zs., eds. Turizmusmarketing esettanulmányok II. (pp. 82-90). Budapest: Akadémiai Kiadó.

[17] Fisher, B., Costanza, R., Ali, S., Beer, C., Budapest Bond, L., Boumans, R., Danigelis, N., Dickinson, J., Elliott, C., Farley, J., Gayer, D., Glenn, L., Hudspeth, T., Mahoney, D., Mcintosh, B., McCahill, L., Snapp, R., Simpatico, T., Rizzo, D. \& Rizvi, S. (2008). An Integrative Approach to Quality of Life Measurement, Research, and Policy. Sapiens. 1(1), not paged. DOI: 10.5194/sapiens-1-11-2008.

[18] Flusser, V. (1996). Az ágy. Budapest: Kijárat.

[19] Gallent, N. (2007). Second homes, community and a hierarchy of dwelling. Area, 39(1), 97106. DOI: 10.1111/j.1475-4762.2007.00721.x.

[20] Halfacree, K. (2012). Heterolocal identities? Counter-urbanisation, second homes, and rural consumption in the era of mobilities. Population, Space and Place, 18(2), 209-224. DOI: $10.1002 / p s p .665$.

[21] Hall, C. M. (2015). Second homes planning, policy and governance. Journal of Policy Research in Tourism, Leisure and Events, 7(1), 1-14. DOI: 10.1080/19407963.2014.964251

[22] Horváth, Z., Magyar-Papp, J., Pálfi, A. (2016). A turisztikai térhasználat és a desztináció menedzsment összefüggései. Modern Geográfia, 11, 1-14.

[23] Horváth, Z., Pálfi, A., Aubert, A. (2018). A desztinációfejlesztés hangsúlyainak változása a balaton turisztikai régióban. Turisztikai és Vidékfejlesztési Tanulmányok, 3(3), 44-56.

[24] Jaakson, R. (1986). Second-home domestic tourism. Annals of Tourism Research, 13(3), 367-391. DOI: 10.1016/0160-7383(86)90026-5.

[25] Jamaludin, M., Aziz, A. \& Idris, N. (2013). Information sources influence destination image. International Journal of Independent Research and Studies, 2(4), 146-155. 
[26] Jeffres, L. \& Dobos, J. (1993). Perceptions of leisure opportunities and the quality of life in a metropolitan area. Journal of Leisure Research, 25(2), 203-217. DOI: 10.1080/00222216.1993.11969918.

[27] Kiryluk, H. \& Glińska, E. (2015). Creation and evaluation of the tourist image of a country the example of Poland. Procedia - Social and Behavioral Sciences, 213, 671-676. DOI: 10.1016/j.sbspro.2015.11.473.

[28] Kiss, K., Kovács, B. \& Michalkó, G. (2020). Boldogsággyár túl az Óperencián - az életminőség-orientált turizmusfejlesztés Ausztriában. Földrajzi Közlemények 144 (1), 13-26. DOI: 10.32643/fk.144.1.2.

[29] Kovács, E., Kiss, K., Pinke-Sziva, I. \& Michalkó, G. (2019). Social impacts of tourism: A critical literature review on the interrelation between well-being and tourism in the case of seniors. In Dogan, G. \& Robin, N., eds., The Routledge handbook of tourism impacts: Theoretical and applied perspectives (pp. 229-241). London: Routledge.

[30] Lőrincz, K., Banász, Zs., Horváth, B. \& Schulcz, A. (2019). A Balaton térsége mint élettér. In: Erdélyi, D., ed., URBAN21 Város, Kultúra, Gazdaság (pp. 61-72). Budapest: Hárfa Alapítvány.

[31] Malhotra, N. K. \& Simon, J. (2009). Marketingkutatás. Budapest: Akadémiai Kiadó.

[32] Marton, G. \& Jónás-Berki, M. (2013). Aktív turizmus pozíciója a Balaton térségében. Modern Geográfia, 8, 1-10.

[33] Michalkó, G., Rátz, T. \& Irimiás, A. (2010). Egy magyarországi fürdőváros lakosságának életminősége: az orosházi eset. Turizmus Bulletin 14(4), 61-68.

[34] Michalkó, G. (2010). Boldogító utazás. A turizmus és az életminőség kapcsolatának magyarországi vonatkozásai. Budapest: MTA Földrajztudományi Kutatóintézet.

[35] Möser, B. \& Weiermair, K. (1998). Travel decision-making: from the vantage point of perceived risk and information preferences. Journal of Travel and Tourism Marketing, 4. 107-121. DOI: 10.1300/J073v07n04_06.

[36] Nawijn, J. (2010). Happiness Through Vacationing: Just a Temporary Boost or Long-Term Benefits? Journal of Happiness Studies, 12. 651-665. DOI: 10.1007/s10902-010-9221-y.

[37] Pálfi, A. \& Aubert A. (2018). A desztinációfejlesztés hangsúlyainak változása a Balaton turisztikai régióban. Turisztikai és Vidékfejlesztési Tanulmányok, 3, 44-56.

[38] Pálfi, A., Nemes, V. \& Horváth, Z. (2015). Tourism destination management offices in the tourism region of Balaton. Transylvanian Journal of Tourism and Territorial Development, 1(1), 70-77.

[39] Piskóti, I., Nagy, Sz., Dankó, L., Molnár, L. \& Marien, A. (2012). A társadalmi marketing paradigmái - elméleti-módszertani alapozó kutatás [research report]. Budapest: Hungarian Scientific research Fund.

[40] Pitkänen, K., Adamiak, C. \& Halseth, G. (2014). Leisure Activities and Rural Community Change: Valuation and Use of Rural Space among Permanent Residents and Second Home Owners. Sociologia Ruralis, 54(2), 143-166. DOI: 10.1111/soru.12023.

[41] Puczkó, L. \& Smith, M. K. (2011). Tourism-Specific Quality of Life Index: The Budapest Model. In: Budruk, M. \& Philips, R., eds., Quality-of-Life Community Indicators for Parks, Recreation and Tourism Management (pp. 163-184). Dordrecht: Springer.

[42] Puczkó, L. \& Rátz, T. (1998). A turizmus hatásai. Budapest: Aula.

[43] Raffay-Danyi, Á. \& Péter, A. (2019). A Balaton, mint turisztikai desztináció és mint második otthon. Comitatus: Önkormányzati Szemle, 29(2), 71- 81.

[44] Ragatz, R. L. (1970). Vacation Homes in the Northeastern United States: Seasonality in Population Distribution. Annals of the Association of American Geographers, 60(3), 447455. 
[45] Rahman, T., Mittelhammer, R. \& Wandschneider, Ph. (2005). Measuring the Quality of Life across Countries: A Sensitivity Analysis of Well-being Indices [working paper]. Helsinki: World Institute for Development Economic Research.

[46] Rogers, A., Castree, N. \& Kitchin, R. (2013). A Dictionary of Human Geography. Oxford University Press.

[47] Rye, J. F. (2011). Conflicts and contestations. Rural populations' perspecitves on the second homes phenomenon. Journal of Rural Studies, 27(3), 263-274. DOI: 10.1016/j.jrurstud.2011.03.005.

[48] Sajtos, L. \& Mitev, A. (2007). SPSS kutatási és adatelemzési könyv. Budapest: ALINEA.

[49] Salazar, N. B. \& Zhang, Y. (2013). Seasonal lifestyle tourism: the case of Chinese elites. Annals of Tourism Research, 43, 81-90. DOI: 10.1016/j.annals.2013.04.002.

[50] Samuels, P. (2014). Independent Samples t-test. [technical report]. Birmingram City University.

[51] Schleicher, V. (2018). Kultúrfürdő - Kulturális kölcsönhatások a Balaton térségében 18221960 között. Budapest: L'Harmattan.

[52] Schuessler, K. \& Fisher, G. (1985). Quality of life research and sociology. Annual Review of Sociology, 11, 129-149. DOI: 10.1146/annurev.so.11.080185.001021.

[53] Shin, D. C. (1980). Subjective indicators and the comparative evaluation of the quality of community life. American Journal of Community Psychology, 8, 523-536. DOI: $10.1007 / B F 00912590$.

[54] Stedman, R. C. (2006). Understanding place attachment among second home owners. American Behavioral Scientist, 50(2), 187-205. DOI: 10.1177/0002764206290633.

[55] Strandell, A. \& Hall, C. M. (2015). Impact of the residential environment on second home use in Finland - Testing the compensation hypothesis. Landscape and Urban Planning, 133, 1223. DOI: 10.1016/j.landurbplan.2014.09.011.

[56] Sulyok, J. \& Madarász, E. (2019). Turista vagy helyi lakos? - A második otthonokhoz kapcsolódó szabadidős fogyasztás vizsgálata. In: Kátay, Á., Michalkó, G. \& Rátz, T., eds., Turizmus 3.0 (pp. 27-40). Orosháza/Budapest: Kodolányi János University, Institute of Geography of HAS, Hungarian Geographical Society.

[57] Sulyok, J. (2013). A Balaton mint vízparti turisztikai desztináció potenciális márkaértékének feltérképezése belföldi vonatkozásban. Turizmus Bulletin, 15, 23-33.

[58] Tombaugh, L. W. (1970). Factors Influencing „Vacation Home Locations”. Journal of Leisure Research, 2(1), 54-63. DOI: 10.1080/00222216.1970.11969983.

[59] Tóth, G. (2005). A magyarországi idegenforgalmi régiókról. Területi Statisztika, 45, 147-162.

[60] Tuan, Y-F. (1977). Space and place: The perspective of experience. Minneapolis, University of Minnesota Press.

[61] Utasi, Á. (2006). A minőségi élet feltételei és forrásai. In: Utasi, Á. (ed.): A szubjektív életminőség forrásai: biztonság és kapcsolatok (pp. 13-49). Budapest: MTA Politikai Tudományok Intézete.

[62] Uysal, M., Perdue, R. \& Sirgy, J., eds. (2012). Handbook of Tourism and Quality of Life Research. Heidelberg: Springer.

[63] Veenhoven, R. (2000). The four qualities of life. Journal of Happiness Studies, 1, 1-39. DOI: 10.1023/A:1010072010360.

[64] Wong, C. (2006). Indicators for urban and regional planning. London: Routledge.

[65] Zawilińska, B. (2020). Residents' Attitudes Towards a National Park Under Conditions of Suburbanisation and Tourism Pressure: A Case Study of Ojców National Park (Poland), European Countryside, 12(1), 119-137. DOI: 10.2478/euco-2020-0007. 
[66] 1861/2016 (XII. 27.) Kormány határozat a Balaton kiemelt turisztikai fejlesztési térség meghatározásáról és a térségben megvalósítandó egyes fejlesztések megvalósitásához szükséges források biztositásáról. Available online: https://net.jogtar.hu/jogszabaly?docid=A16H1861.KOR\&txtreferer=00000003.TXT (accessed on 20 April 2020).

[67] 2000. évi CXII. törvény a Balaton Kiemelt Üdülökörzet Területrendezési Tervének elfogadásáról és a Balatoni Területrendezési Szabályzat megállapításáról. Available online: https://mkogy.jogtar.hu/jogszabaly?docid=a0000112.TV (accessed on 20 April 2020).

[68] 429/2016 (XII. 15.) Kormány rendelet a turisztikai térségek és a kiemelt turisztikai fejlesztési térségek meghatározásáról. Available online: https://net.jogtar.hu/jogszabaly?docid=A1600429.KOR\&txtreferer=00000001.TXT (accessed on 20 April 2020).

[69] A Balaton üdülőkörzet társadalmi helyzetképe. ISBN 978-963-235-376-0 Available online: http://www.ksh.hu/docs/hun/xttp/idoszaki/regiok/balatontarsadalmi.pdf (accessed on 30 November 2020).

[70] Dissemination database of HCSO (Hungarian Central Statistical Office). Available online: $\mathrm{http}: / /$ statinfo.ksh.hu/Statinfo/themeSelector.jsp?page=2\&szst=OGT\&lang=en (accessed on 20 April 2020).

[71] MTH (2005). Nemzeti Turizmusfejlesztési Stratégia 2005-2013. Magyar Turisztikai Hivatal, Budapest. 210 p.

[72] MTÜ (2017). Nemzeti Turizmusfejlesztési Stratégia 2030. Magyar Turisztikai Ügynökség, Budapest. $154 \mathrm{p}$. 